DOI https://doi.org/10.15589/znp2019.3(477).2

УДК 621.036 .07

\title{
HEAT AND HARMFUL EMISSIONS \\ FROM GASES BURNING OF WATER-FUEL EMULSIONS
}

\section{ТЕПЛОВІ ТА ШКІДЛИВІ ВИКИДИ ДИМОВИХ ГАЗІВ ПІД ЧАС СПАЛЮВАННЯ ВОДОПАЛИВНИХ ЕМУЛЬСІЙ}

\author{
Oleksandr M. Filipshchuk \\ filipschuk5@gmail.com \\ ORCID: 0000-0003-4061-7577 \\ Oleg V. Kolbasenko \\ orden2020@gmail.com \\ ORCID: 0000-0001-9460-4558
}

\author{
О. М. Філіпщук, \\ ст. викладач
}

О. В. Колбасенко,

аспірант

Admiral Makarov National University of Shipbuilding, Mykolaiv

Начіональний університет кораблебудування імені адмірала Макарова, м. Миколаїв

\begin{abstract}
The purpose of the research is to increase the environmental efficiency of ship boilers using water emulsions with high water content and correction of its composition. The method of research is experimentally calculated. In order to increase the reliability of the assessment of the impact of cavitation preparation on the environmental indicators of the water content of the RES, studies were carried out on a pilot plant that ensures the stability of combustion parameters and the values of toxic values. The quality control of combustion fuel oil and water-fuel emulsion was carried out using a "Gasochrome-3101" chromatograph and an "OKSI-5M" gas sensor to determine the concentration of toxic emissions of $\mathrm{SO}_{2}, \mathrm{NO}_{\mathrm{x}}$ (and separately $\mathrm{NO}$ and $\mathrm{NO}_{2}$ ) and $\mathrm{CO}_{2}$. The relative error is at $\pm 5 \%$. As shown by the scientific researches at combustion of water-fuel emulsions with a water capacity of $25-30 \%$ (primary method of purification), a decrease in the output of the combustion chamber of the experimental installation of the concentration of $\mathrm{NO}_{x}$ by 3,8 times, $\mathrm{SO}_{2}$ by 2,5 times and $\mathrm{CO}_{2}$ is ensured by $25 \%$ as a result of the reduction of the PES fuel content. On the condensation surfaces of boilers (the second stage of purification) with sulfuric acid condensate with a concentration of about $57 \%$, the content of $\mathrm{NO}_{x}$ oxides is reduced by 1,7 times and sulfur $\mathrm{SO}_{2}$ by 10 times. While providing the condensation process in the pipeline (the third stage of purification), additional gases from $\mathrm{NO}_{x}$ and $\mathrm{SO}_{2}$ will be purified by absorption. Unlike the existing scrubber technologies, the proposed system of cleaning in the fourth stage irrigates the surface of the scrubber catholyte from the dial. To increase the $\mathrm{pH}$ of the catholyte to the level of $8,5-9,5$, (increasing the number of ions $\mathrm{H}^{+}, \mathrm{OH}^{-}$) installed cavitator, which will increase the intensity of the absorption processes in the scrubber. Thus, the use of scrubber technology in the combustion of water-fuel emulsion with $\mathrm{W}^{\mathrm{r}}=25-30 \%$ can reduce the $\mathrm{NO}_{x}$ concentration by 26 times, $\mathrm{SO}_{2}$ by 13,6 times, and $\mathrm{CO}_{2}$ by 2,4 times compared to the burning of fuel oil. The dimensions of the scrubber sections for $\mathrm{NO}_{x}$ capture will decrease by 3-4 times, and the $\mathrm{CO}_{2}$ capture sections will decrease by 5-8 times taking into account the increase of $\mathrm{CO}_{2}$ absorption by the nitrous mechanism.
\end{abstract}

Key words: water-fuel emulsion; water electrodialysis; cavity; combustion; toxic gas emissions; absorption; condensation surfaces; scrubber; thermal emissions.

Анотація. Мета дослідження - підвищення екологічної ефективності суднових котельних установок, що використовують водопаливні емульсії з підвищеним водовмістом і корекцією іiї складу. Метод дослідження експериментально-розрахунковий. Для підвищення достовірності оцінки впливу кавітаційної підготовки та водовмісту водопаливних емульсій на екологічні показники дослідження було проведено на експериментальній установці, що забезпечує сталість параметрів горіння й величин викидів токсичних речовин. Контроль якості горіння мазуту та водопаливних емульсій здійснювався за допомогою хроматографа «Газохром-3101» та газоаналізатора «ОКСІ-5М» із метою визначення концентрації токсичних викидів $\mathrm{SO}_{2}, \mathrm{NO}_{\mathrm{x}}$ (та окремо $\mathrm{NO}$ i $\mathrm{NO}_{2}$ ) i $\mathrm{CO}_{2}$. Відносна похибка перебуває на рівні $\pm 5 \%$. Як показали проведені наукові дослідження, під час спалювання водопаливних емульсій із водомісткістю 25-30\% (первинний метод очистки) забезпечується зниження на виході

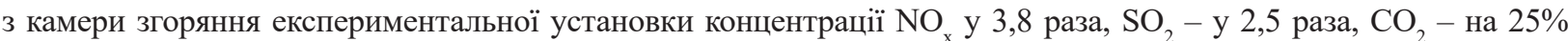
унаслідок зменшення вмісту чистого палива у водопаливних емульсіях. На конденсаційних поверхнях котлів (другий етап очистки) конденсатом сірчаної кислоти з концентрацією близько $57 \%$ вміст оксидів азоту $\mathrm{NO}_{\mathrm{x}}$ зменшується в 1,7 раза, сірки $\mathrm{SO}_{2}$ - у 10 разів. Під час забезпечення процесу конденсації в газоході (третій етап очистки ) буде здійснюватися додаткова очистка газів від $\mathrm{NO}_{x}$ i $\mathrm{SO}_{2}$ за рахунок абсорбції. На відміну від 


\section{ЕНЕРГЕТИЧНЕ МАШИНОБУДУВАННЯ № 3 2019}

наявних скруберних технологій, у запропонованій системі очистки на четвертому етапі на зрошення поверхні скрубера підводиться католіт від електродіалізатора. Для підвищення $\mathrm{pH}$ католіту до рівня 8,5-9,5 (збільшення кількості іонів $\left.\mathrm{H}^{+}, \mathrm{OH}^{-}\right)$встановлено кавітатор, що забезпечить підвищення інтенсивності абсорбційних процесів у скрубері. Таким чином, використання скруберних технологій під час спалювання водопаливних емульсій із $\mathrm{W}^{\mathrm{r}}=25-30 \%$ дає змогу знизити концентрацію $\mathrm{NO}_{x}$ у 26 разів, $\mathrm{SO}_{2}-$ у 13,6 раза, а $\mathrm{CO}_{2}-$ у 2,4 раза порівняно зі спалюванням мазуту. Розміри секцій скрубера для уловлення $\mathrm{NO}_{x}$ зменшаться в 3-4 рази, а секції уловлення $\mathrm{SO}_{2}$ з урахуванням зростання абсорбції $\mathrm{SO}_{2}$ за нітрозного механізму зменшаться в 5-8 разів.

Ключові слова: водопаливна емульсія; електродіаліз води; кавітація; горіння; токсичні викиди газів; абсорбція; конденсаційні поверхні; скрубер; теплові викиди.

\section{ВСТУП}

Необхідність виконання всіх вимог міжнародних і державних організацій у сфері охорони навколишнього середовища за одночасного зменшення теплових втрат під час спалювання органічних палив, вартість яких зростає, підвищення економічності й надійності роботи всіх елементів суднових енергетичних установок (далі СЕУ) зумовлюють розгляд усіх можливостей виконання вказаних завдань у вигляді комплексної технології послідовно на всіх етапах: підготовки палива до спалювання, самого процесу горіння, процесів тепломасообміну в конденсаційних поверхнях нагрівання котлів.

\section{ПОСТАНОВКА ЗАДАЧІ}

Найбільш ефективним та економічно обгрунтованим методом зниження концентрації оксидів азоту й сірки в теплоенергетиці сьогодні є термохімічний. Досвід застосування цього методу визначає два основні способи подачі води в циліндр двигуна для іiї використання у процесі горіння палива: через паливну систему у вигляді водопаливної емульсії (далі - ВПЕ) та за рахунок безпосереднього впорскування води й водяної пари через спеціальну форсунку. До радикальних і досить простих способів зниження вмісту сірчистих сполук та оксидів азоту в димових газах енергетичних установок належить очистка вихлопних газів за допомогою скруберних технологій.

\section{АНАЛІЗ ОСТАННІХ ДОСЛІДЖЕНЬ І ПУБЛІКАЦІЙ}

Відомі способи очищення відхідних газів від токсичних сполук представлені в багатьох публікаціях, наприклад [1-6].

На думку спеціалістів фірми MAN [1], вимоги IMO (III рівень 3 емісії $\mathrm{SO}_{x}, \mathrm{NO}_{x}$ ) можна виконати за допомогою таких технологій:

- використання водопаливної емульсії - WIF (Water in Fuel emulsion);

- зволоження наддувного повітря - SAM (Scavenge Air Monistening);

- рециркуляції вихлопних газів - EGR (Exhaust Gas Recirculation);

- селективного каталітичного зниження емісії $\mathrm{NO}_{\mathrm{x}}$-SCR (Selective Catalytic Reduction).

У гібридній системі очищення Alfa Laval та Aalborg Industries [2] першою стадією очистки вва- жається утилізаційний котел, у якому вихлопні гази охолоджуються від $350^{\circ} \mathrm{C}$ до $160-180^{\circ} \mathrm{C}$ та спостерігається забруднення поверхонь утилізаційного котла, що розглядається як етап очистки від твердих часток. На другій стадії очистки за рахунок використання скрубера Вентурі під час впорскування води триває зниження температури вихлопних газів та очистка від твердих часток за рахунок їх зволоження.

Особливістю системи $\mathrm{CSNO}_{\mathrm{x}}$ [3] $є$ використання попередньо обробленої морської води з метою підвищення іiі лужності та показника $\mathrm{pH}$. Під час скруберування підвищення значень $\mathrm{pH}$ і лужності цієї води різко знижують окислювальну дію $\mathrm{CO}_{2}, \mathrm{SO}_{2}$ та $\mathrm{NO}_{x}$. Обробка води, унаслідок якої суттєво підвищуються її абсорбційні властивості, проводиться із застосуванням електричних засобів, без хімічних реагентів. У цій технології насамперед розглядаються тільки можливості збільшення абсорбційної здібності води як абсорбенту та зовсім не розглядаються можливості збільшення абсорбційної можливості димових газів як абсорбата.

Випробування системи $\mathrm{CSNO}_{x}$ показали, що за значень вмісту токсичних речовин на виході з головного котла паропродуктивністю 60 т/год концентрації $\mathrm{SO}_{2}$ на рівні 669,3 ppm, $\mathrm{NO}_{x}$ на рівні $158,5 \mathrm{ppm}$ та $\mathrm{CO}_{2}$ на рівні $5,16 \%$ на виході зі скрубера вміст цих же інгредієнтів становив: 47,4 ppm - $\mathrm{SO}_{2}, 28,2 \mathrm{ppm}-$ $\mathrm{NO}_{x}, 1,32 \%-\mathrm{CO}_{2}$. Тобто емісія основних шкідливих речовин знизилася: $\mathrm{SO}_{2}$ - на $92,9 \%, \mathrm{NO}_{\text {x }}$ - на $82,2 \%$, $\mathrm{CO}_{2}-$ на $74,4 \%$. Під час очистки вихлопних газів після двигунів внутрішнього згоряння (далі - ДВ3) марки 6 $550 \mathrm{MC}$, у якому спалювалося паливо з $\mathrm{S}^{\mathrm{r}}=3,64 \%$, випробування показало, що за вмісту токсичних речовин на виході з ДВ3 на рівні 846,05 ppm SO $, 709,26$ ppm $\mathrm{NO}_{x}$ та $3,99 \% \mathrm{CO}_{2}$ на виході зі скрубера вміст цих же інгредієнтів становив: $10,75 \mathrm{ppm}-\mathrm{SO}_{2}, 243,11$ $\mathrm{ppm}-\mathrm{NO}_{x}, 0,93 \%-\mathrm{CO}_{2}$. Емісія основних шкідливих речовин знизилася в такому співвідношенні: $\mathrm{SO}_{2}-$ $98,7 \%, \mathrm{NO}_{\mathrm{x}}-65,7 \%, \mathrm{CO}_{2}-76,7 \%$ [3]. Вказана ефективність використання скруберної технології прийнята за основу під час оцінки застосування мокрих скруберів у розробленій комплексній технології. Таке ж зниження інтенсивності концентрації $\mathrm{NO}_{\mathrm{x}}$ має місце під час спалювання ВПЕ з $\mathrm{W}^{\mathrm{r}}=30 \%$ у ДВ3 [6; 7].

У статті [7] наведено результати експериментальних досліджень із визначення концентрацій 
у відпрацьованих газах оксидів азоту, оксиду вуглецю, газоподібних вуглеводнів та димності відпрацьованих газів під час роботи автотракторного дизеля 4ЧН 12/14 (СМД-19Т) на стандартному дизельному паливі та водопаливній емульсії, яка має назву «паливо екологічно чисте дизельне» (далі - ПЕД) i випускається Кременчуцьким нафтопереробним заводом, з вмістом води 12,3\%, 19,4\%, 23,2\%, 31,2\% по масі (у разі порівняння з результатами проведених досліджень) з трьома рівнями диспергації ПЕД, що визначалася за діаметром крапель води: 0 - груба диспергація (середній діаметр крапель води в ПЕД 8-9 мкм), 1 - поліпшена диспергація (середній діаметр крапель води в ПЕД 5-6 мкм), 2 - тонка диспергація (середній діаметр крапель води в ПЕД 2-3 мкм). На режимах максимальної потужності відповідно до водовмісту ПЕД концентрація у відпрацьо-

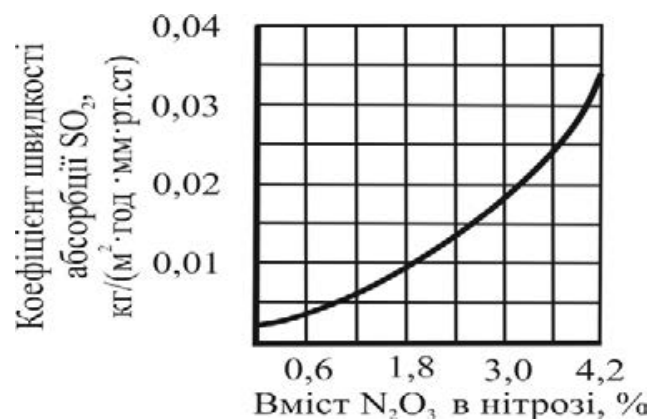

a)

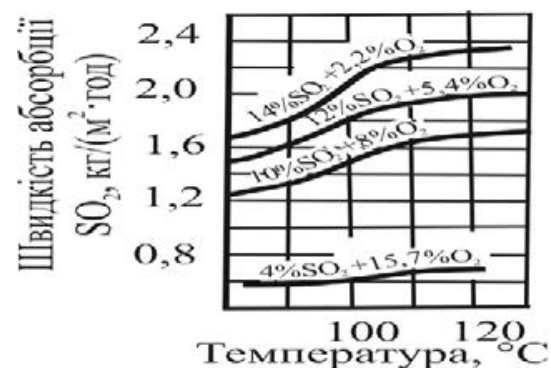

б)

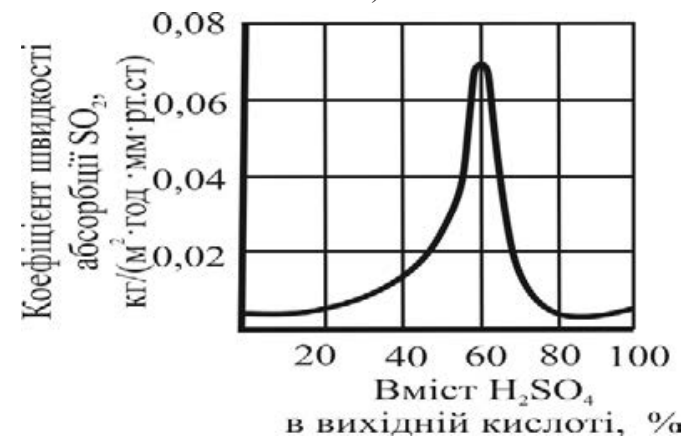

B)

Рис. 1. Залежність швидкості абсорбції $\mathrm{SO}_{2}$ нітрозою від вмісту $\mathrm{N}_{2} \mathrm{O}_{3}$ в нітрозі (a), від температури (б) і вмісту $\mathrm{H}_{2} \mathrm{SO}_{4}$ в вихідній кислоті (в) [8] ваних газах оксидів азоту знижується в 1,3-3,5 раза, концентрація оксиду вуглецю знижується в 1,3-2 рази, димність відпрацьованих газів знижується в 1,6-2,5 раза. Уповільнення реакцій утворення $\mathrm{NO}_{x}$, автори [6; 7] пов'язують із нагріванням, випаровуванням води та перегрівом пари в циліндрі дизеля. Більш тонка диспергація ПЕД (середній діаметр крапель води в ПЕД 1-2 мкм) знижує концентрацію у відпрацьованих газах оксиду вуглецю на 20-30 ррm та димність відпрацьованих газів на 2\% [7]. Однак при цьому збільшується концентрація оксидів азоту на 60-160 ppm. Тобто необхідно враховувати вплив рівня кавітаційної обробки емульсії на підвищення екологічної ефективності. ВПлив ПЕД і рівня його диспергації на концентрацію у відпрацьованих газах газоподібних вуглеводнів є незначним та неоднозначним.

Як відомо з теорії фізико-хімічних процесів сірчанокислотного виробництва за нітрозним механізмом [8], забезпечення еквімолярного або близького до нього співвідношення $\mathrm{NO}_{2}: \mathrm{NO}$ (рис. 1) приводить до відповідного вмісту $\mathrm{N}_{2} \mathrm{O}_{3}$ у нітрозі (рис. $1, a$ ) за температур $80-130^{\circ} \mathrm{C}$ (рис. 1,6 ), що відповідає температурам на низькотемпературних поверхнях нагрівання котлів, і в разі забезпечення відповідної концентрації $\mathrm{H}_{2} \mathrm{SO}_{4}$ (середнє значення 57\%) (рис. 1, 8) різко зростає інтенсивність абсорбції $\mathrm{SO}_{2}$ (у 6-8 разів). Якщо забезпечити такі умови під час спалювання ВПЕ, то можна інтенсифікувати процеси абсорбції та зменшити розміри скруберів [9; 10]. Крім того, у зв'язку з різким зменшенням інтенсивності низькотемпературної корозії за температур металу від $130^{\circ} \mathrm{C}$ до $70^{\circ} \mathrm{C}$ можна знизити температуру газів на виході з котла до рівня $80-90^{\circ} \mathrm{C}$, що суттєво зменшує втрату теплоти з відхідними газами 3 котлів (зазвичай ця температура перебуває на рівні $\left.150-170^{\circ} \mathrm{C}\right)$, що забезпечує зниження рівня теплових викидів в 1,6 раза.

Мета дослідження - підвищення екологічної ефективності суднових котельних установок, які використовують водопаливні емульсії на основі сірчистих мазутів із підвищеним водовмістом і корекцією її складу.

Об'єкт дослідження - вплив на екологічну ефективність котельних установок процесів підготовки та використання водопаливних емульсій на основі сірчистих мазутів.

Предмет дослідження становлять закономірності та показники зменшення викидів токсичних речовин і теплових викидів під час підготовки й використання водопаливних емульсій залежно від їх водовмісту.

Завдання дослідження - визначити вплив складу водопаливних емульсій різного водовмісту та впорскування водяної пари на величину викидів токсичних речовин. 


\section{ЕНЕРГЕТИЧНЕ МАШИНОБУДУВАННЯ № Зロ 2019}

Для цього необхідно дослідити такі процеси: 1) збільшення глибини очищення димових газів від токсичних речовин; 2) активізацію та підвищення якості ВПЕ з метою зниження екологічних показників; 3) активізацію абсорбційних властивостей води, що подається на зрошення скрубера; 4) підвищення абсорбційної активності димових газів щодо $\mathrm{NO}_{\text {x }}$ $\left.\mathrm{SO}_{2}, \mathrm{CO}_{2} ; 5\right)$ зменшення теплових викидів за рахунок зниження втрат теплоти з відхідними газами в разі встановлення конденсаційних поверхонь на виході газів із котлів (допоміжних, утилізаційних).

\section{МЕТОДИ, ОБ'ЄКТ ТА ПРЕДМЕТ ДОСЛІДЖЕННЯ}

Метод дослідження - експериментально-розрахунковий. Для підвищення достовірності оцінки впливу різних факторів (коефіцієнту надлишку повітря, сірки в паливі та особливо водовмісту ВПЕ) дослідження було проведено на експериментальній установці, що забезпечує сталість параметрів горіння ВПЕ та величин викидів токсичних речовин.

Контроль якості горіння мазуту та ВПЕ на їх основі проконтрольовано за допомогою хроматографа «Газохром-3101» (вимірювання концентрації $\mathrm{H}_{2}$, $\mathrm{CO}, \mathrm{CH}_{4}, \mathrm{O}_{2}$ ) і газоаналізатора «ОКСІ-5M» із метою визначення концентрації токсичних викидів $\mathrm{SO}_{2}, \mathrm{NO}_{x}$ (та окремо $\mathrm{NO}$ i $\mathrm{NO}_{2}$ ). Порогова чутливість цих газоаналізаторів (в об. \%) становить: $5 \times 10^{-1}$ за $\mathrm{H}_{2}, 1 \times 10^{-3}$ за $\mathrm{CO}$ i $\mathrm{CH}_{4}, \mathrm{SO}_{2}, \mathrm{NO}_{x}, 2 \times 10^{-2}$ за $\mathrm{O}_{2}$. Відносна похибка перебуває на рівні $\pm 5 \%$.

\section{ОСНОВНИЙ МАТЕРІАЛ}

Для виконання поставленої мети в запропонованій технології для забезпечення комплексного вирі- шення завдань із покращення екологічних показників передбачається:

1) спалювання ВПЕ відповідної якості з водомісткістю близько $\mathrm{W}^{\mathrm{r}}=30 \%$, що $є$ первинним методом зниження токсичності газів;

2) електродіалізна підготовка води необхідної якості для зрошення насадки скрубера для забезпечення інтенсифікації ії абсорбційних властивостей унаслідок підвищення концентрації іонів $\mathrm{H}^{+}$та $\mathrm{OH}^{-}$ під час обробки води потужним електричним полем;

3) встановлення конденсаційних низькотемпературних поверхонь нагрівання (далі - НТПН), на поверхні яких створені умови пасивації металу та різкого зниження інтенсивності низькотемпературної корозії, що дає змогу не лише знизити теплові викиди, а й підвищити інтенсифікацію абсорбції $\mathrm{NO}_{x}, \mathrm{SO}_{2}, \mathrm{CO}_{2}$ конденсатом сірчаної кислоти;

4) продовження інтенсифікації абсорбції на конденсаційних поверхнях газоходів до скрубера;

5) встановлення мокрих скруберів із метою забезпечення остаточних показників токсичності згідно 3 останніми вимогами.

Як показали проведені наукові дослідження, що пов'язані 3 розвитком теплових і фізико-хімічних процесів в елементах СЕУ, під час розроблення технології комплексної системи зниження екологічних показників і теплових втрат $\epsilon$ організація процесу спалювання в паливоспалюючих агрегатах СЕУ кавітаційно підготовлених ВПЕ (на основі сірчистих палив) із водомісткістю 25-30\% [10; 11]. Для виконання завдання активізації абсорбційних властивостей димових газів, що відрізняє розроблену технологію від існуючих аналогів, необхідно забезпечити еквімо-

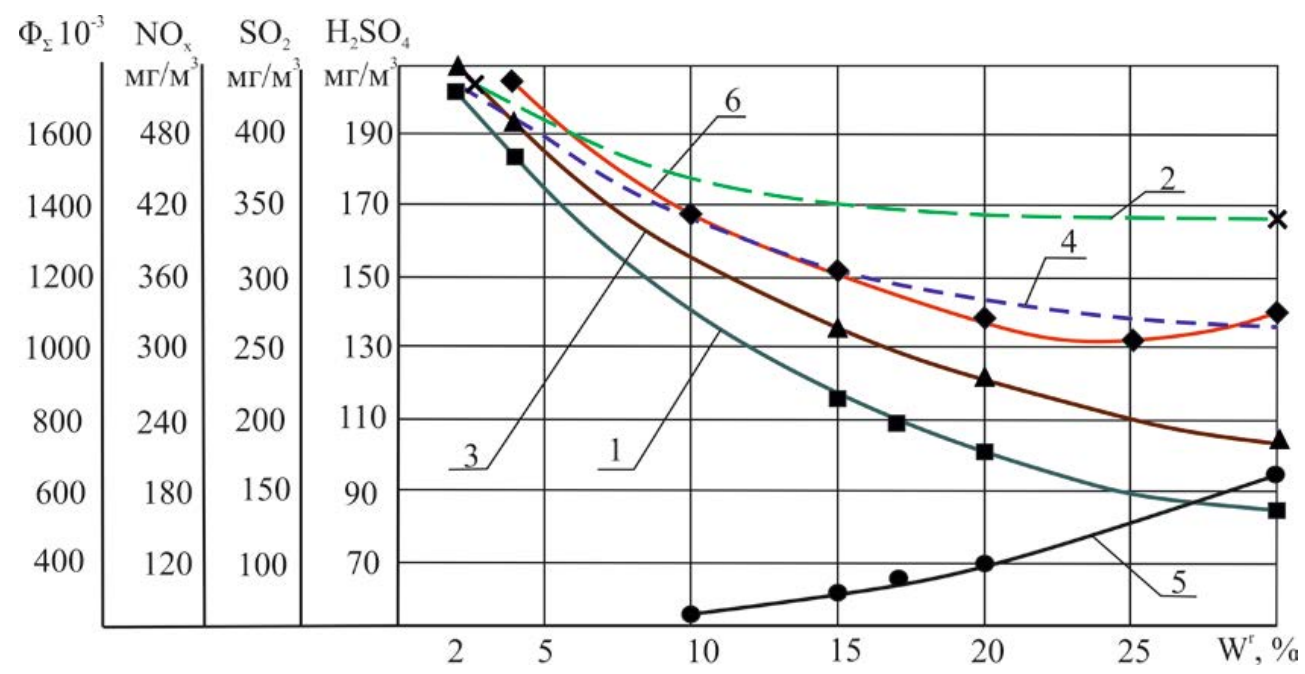

Рис. 2. Залежність емісії $\mathrm{SO}_{2}, \mathrm{NO}_{\mathrm{x}}, \mathrm{H} 2 \mathrm{SO}_{4}$ від водовмісту ВПЕ Wr і способу введення води (пари):

$\mathrm{NO}_{x}\left(1\right.$ - водомазутна емульсія на основі мазуту M40; 2 -мазут $\mathrm{M} 40+$ водяна пара); $\mathrm{SO}_{2}(3$ - водомазутна емульсія на основі мазуту М40; 4 -мазут M40 + водяна пара); 5 - пара сірчаної кислоти $\mathrm{H}_{2} \mathrm{SO}_{4} ; 6-$ сумарна токсичність $\Phi_{\Sigma}$ 
лярне (або близьке до цього) співвідношення $\mathrm{NO}_{2}: \mathrm{NO}$ в газах. Як показали наші наукові дослідження, таке співвідношення (або близьке до нього) природно створюється в кінці зони горіння ВПЕ з водовмістом 25-30\% унаслідок впливу інтенсивної турбулентності, що створюється за мікровибухів крапель ВПЕ та зниження середньої температури газів у зоні активного горіння. Унаслідок дії розглянутих процесів спостерігається зниження на виході 3 камери згоряння експериментальної установки концентрації $\mathrm{NO}_{\text {в в } 3,8}$ раза (з $533 \mathrm{мг} / \mathrm{M}^{3}$ до $167 \mathrm{мг} / \mathrm{M}^{3}$ ), $\mathrm{SO}_{2}$ - у 2,5 раза (з 449 $\mathrm{Mг} / \mathrm{M}^{3}$ до $183 \mathrm{мг} / \mathrm{M}^{3}$ ) (рис. 2). За температури газів нижче $300^{\circ} \mathrm{C}$ (перед економайзером) з'являється аерозоль $\mathrm{H}_{2} \mathrm{SO}_{4}$, як і в сірчанокислотному виробництві за нітрозним механізмом [8]. Концентрація $\mathrm{CO}_{2}$ знижується внаслідок зменшення вмісту чистого палива у ВПЕ на 25\%. Таким чином, за первинного методу (використання ВПЕ з водовмістом 25-30\%) досягається суттєве зниження викидів токсичних $\mathrm{NO}_{\mathrm{x}}, \mathrm{SO}_{2} \mathrm{i} \mathrm{CO}_{2}$.

У разі вводу водяної пари в зону активного горіння в кількості, що відповідає 30-відсотковій ВПЕ, викиди $\mathrm{NO}_{x}$ збільшуються в 2,4 раза, а викиди $\mathrm{SO}_{2}$ - у 1,5 раза порівняно зі спалюванням ВПЕ. При цьому зменшується співвідношення $\mathrm{NO}_{2}$ : $\mathrm{NO}$ від 0,33 до 0,27 , тобто в 1,25 раза (рис. 3 ), що погіршує абсорбційні властивості газів.

Особливістю режиму спалювання такого складу ВПЕ $3 \mathrm{~W}^{\mathrm{r}}$ на рівні 25-30\% є поява на виході із зони горіння (унаслідок природного проходження фізико-хімічних процесів) у складі димових газів суміші оксидів азоту $\mathrm{NO}_{\text {x }}$ зі співвідношенням компонентів $\mathrm{NO}_{2}$ : $\mathrm{NO}$, близьким до еквімолярного співвідношення 0,33 , за якого за температур поверхні, що нижчі за температуру точки роси пари $\mathrm{H}_{2} \mathrm{SO}_{4}$, спостерігається найбільш інтенсивна абсорбція конденсатом сірчаної кислоти оксидів азоту та $\mathrm{SO}_{2}$, оскільки природно за $\mathrm{t}_{\text {ст }}=110^{\circ} \mathrm{C}$ складається концентрація сірчаної кислоти на рівні 57\%, за якої різко зростає абсорбція $\mathrm{SO}_{2}$.

Проведені експериментальні дослідження показують, що шаром забруднень, зволожених конденсатом сірчаної кислоти 3 концентрацією близько 57\% унаслідок відповідної організації фізико-хімічних процесів і природно створюваних умов максимальної інтенсивності абсорбції, вміст оксидів азоту $\mathrm{NO}_{\text {х }}$ сірки $\mathrm{SO}_{2}$ після конденсаційної поверхні суттєво знижується: 1 м $^{2}$ конденсаційної поверхні абсорбує близько 3,4 $\mathrm{Mг} / \mathrm{M}^{3} \mathrm{NO}_{\text {x }}$ та $0,9 \mathrm{Mr} / \mathrm{M}^{3} \mathrm{SO}_{2}$, що дає можливість залежно від величини конденсаційної поверхні (наприклад,

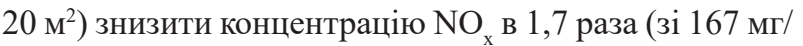

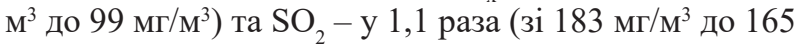
$\left.\mathrm{M \Gamma} / \mathrm{M}^{3}\right)$. При цьому важливо, що додатково спостерігається процес осадження токсичних твердих золових $\mathrm{i}$ сажистих часток зі 150-170 мг/м ${ }^{3}$ (на виході 3 топки під час спалювання ВПЕ з $\mathrm{W}^{\mathrm{r}}=30 \%$ ) до 50-60 мг $/ \mathrm{M}^{3}$ після конденсаційної поверхні.
Забезпечення процесу абсорбції оксидів $\mathrm{NO}_{\text {x }}, \mathrm{SO}_{2}$ конденсатом сірчаної кислоти на конденсаційних поверхнях котлів розглядається як другий етап очистки відхідних газів від токсичних інгредієнтів.

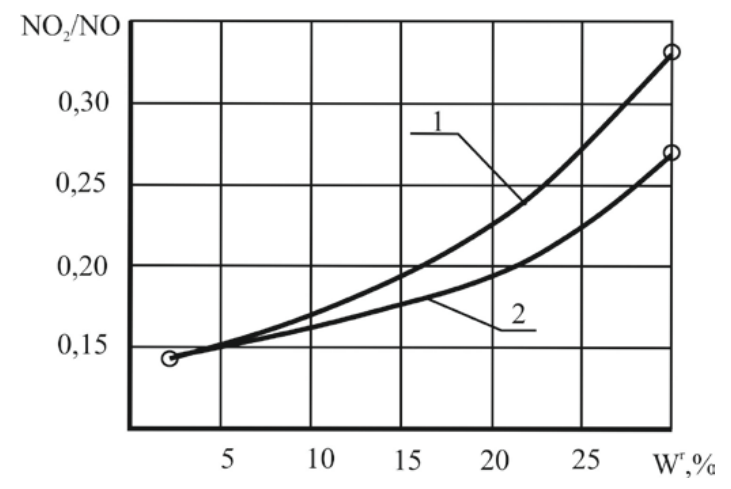

Рис. 3. Залежності відношення $\mathrm{NO}_{2}: \mathrm{NO}$ в димових газах від способу введення води під час спалювання стандартного мазуту M40 ( $\left.\mathrm{S}^{\mathrm{r}}=1,8 \%\right)$ і водомазутної емульсії на основі мазуту M40, приготованої на основі стандартного мазуту M40 (кількість введеної до кореню факела водяної пари є еквівалентною вмісту води у водомазутній емульсії):

1 - мазут M40 (Wr = 2,0\%) і водомазутна емульсія на основі мазуту М40; 2 - мазут M40 ( $\left.W^{r}=2,0 \%\right)$ в впорскування водяної пари

Залежно від конструктивного виконання та перебігу теплових і фізико-хімічних процесів у газоходах після допоміжних котлів та утилізаційних котлів після ДВЗ температура газів на вході у скруберну частину кожного з газоходів пропонованої системи становитиме $80-90^{\circ} \mathrm{C}$ (і цей показник є нижчим порівняно 3 прототипом - технологією CSNO, де температура газів після котлів і ДВ3, де спалюється сірчисте паливо $3 \mathrm{~W}^{\mathrm{r}}=2 \%$, перебуває на рівні $150-170^{\circ} \mathrm{C}$ і вище). Це приводить до суттєвого зниження витрат води, що необхідна для зрошення скруберів, та зменшення їх розмірів.

Після конденсаційних поверхонь, що встановлені на виході з допоміжних та утилізаційних котлів, димові гази потрапляють у газоходи. Після конденсаційної поверхні концентрація пари кислоти в газах стане нижчою, відповідно, знизиться також ії температура точки роси $\mathrm{H}_{2} \mathrm{SO}_{4}$, що полегшує захист металу газоходів після конденсаційної НТПН.

Важливим для здійснення наступних етапів очистки димових газів, оцінки корозійного впливу на метал газоходів пари $\mathrm{H}_{2} \mathrm{SO}_{4}$ та $\mathrm{H}_{2} \mathrm{O} \epsilon$ те, що в ході фізико-хімічних процесів у шарі конденсату й забруднень, які є на конденсаційних поверхнях, знижується концентрація $\mathrm{NO}_{x}$, а також (що важливо) збільшується вміст у них $\mathrm{NO}_{2}$, що забезпечує еквімолярне співвідношення $\mathrm{NO}: \mathrm{NO}_{2}$ в потоці газів після конденсаційної теплообмінної поверхні котла. Отже, з'являється можливість (перший варіант) під час спалювання ВПЕ із застосуванням скруберної технології для до- 


\section{ЕНЕРГЕТИЧНЕ МАШИНОБУДУВАННЯ № 3 2019}

поміжних котлів за наявності конденсату $\mathrm{H}_{2} \mathrm{SO}_{4}$ на внутрішній металевій поверхні газоходу (у районі та після НТПН) забезпечити пасивацію поверхні металу газоходу під час подальшого процесу очистки димових газів від $\mathrm{NO}_{x}, \mathrm{SO}_{2}$ за тим же механізмом, що й у попередній конденсаційній поверхні нагріву на виході з котлів (спосіб захисту від низькотемпературної корозії [12]). Для забезпечення процесу конденсації газохід повинен мати таку товщину ізоляції, щоб забезпечити температуру стінки, яка буде нижчою за температуру точки роси $\mathrm{H}_{2} \mathrm{SO}_{4}$ в цьому газоході, i перепад температур газів та стінки на рівні $10-15^{\circ} \mathrm{C}$, за якого відбуватиметься конденсація. За такого теплоперепаду забезпечується мінімальний рівень корозії (перший варіант) і додатково відбувається процес пасивації металу, що підвищує надійність поверхонь; крім того, буде забезпечена додаткова очистка газів від $\mathrm{NO}_{\text {x }}$ i $\mathrm{SO}_{2}$ за рахунок абсорбції.

Можливе прийняття й інших методів захисту металу газоходу (другий варіант): підігрів металу газоходу гарячою водою (або повітрям), що одержана в підігрівачі після скрубера, до рівня, коли буде відсутня конденсація пари $\mathrm{H}_{2} \mathrm{SO}_{4}$. За другого варіанту в газоході процес очистки газів від токсичних інгредієнтів буде відсутнім.

Таким чином, наведені процеси забезпечують третій етап очистки димових газів.

Щоб забезпечити кінцеву очистку димових газів від $\mathrm{NO}_{\text {x }}$ i $\mathrm{SO}_{2}$ до рівня, що запланований нормативними документами IMO, необхідне використання скруберних технологій.

На відміну від наявних скруберних технологій, у запропонованій системі очистки на четвертому етапі на зрошення поверхні скрубера підводиться католіт від електродіалізатора. Для підвищення $\mathrm{pH}$ католіту до рівня 8,5-9,5 (збільшення кількості іонів $\mathrm{H}^{+}, \mathrm{OH}^{-}$) встановлено кавітатор, що забезпечить підвищення інтенсивності абсорбційних процесів у скрубері [10].

$\mathrm{У}$ разі спалювання ВПЕ з водовмістом близько $\mathrm{W}^{\mathrm{r}}$ $=30 \%$ завдяки використанню вже розглянутих етапів очистки газів у їх складі вміст токсичних інгредієнтів перед скруберами перебуватиме на значно нижчому рівні порівняно із системою очистки, що прийнята як прототип (за $\mathrm{W}^{\mathrm{r}}=2 \%$ ) (система $\mathrm{CSNO}_{\mathrm{x}}$ ).

3 метою очищення відхідних газів за допомогою скруберних технологій після виходу газів із допоміжних котлів та утилізаційних котлів після головних двигунів на кожному газоході встановлюються свої окремі скруберні установки: зі зрошувальним циклоном під час спалювання малосірчистих палив та мокрі скрубери послідовного очищення газів головних двигунів і допоміжних котлів від $\mathrm{SO}_{2}, \mathrm{NO}_{\mathrm{x}}$ та $\mathrm{CO}_{2}$ під час спалювання високосірчистих палив (класифікаційні товариства на суднах вимагають установки окремих газоходів головних двигунів, допоміжних котлів, дизель-генераторів).
Температура католіту повинна бути на рівні температури забортної води та обов'язково нижчою за температуру точки роси водяної пари, що перебуває в димових газах (під час спалювання ВПЕ з $\mathrm{W}^{\mathrm{r}}=30 \%$ ii значення перебуває на рівні $48-50^{\circ} \mathrm{C}$ залежно від водомісткості емульсіі). У цьому разі буде забезпечена конденсація водяної пари газів, що буде супроводжуватися (додатково до теплоти абсорбції) виділенням великої кількості теплоти. Унаслідок цього вода на виході з насадки після перемішування з потоком газів підігріється до 80-90 $\mathrm{C}$ (рівень температури забезпечується регулюванням витрат католіту на зрошення насадки в разі забезпечення необхідного рівня абсорбції $\mathrm{NO}_{x}, \mathrm{SO}_{2}, \mathrm{CO}_{2}$ ). У разі забезпечення відповідного рівня лужності води, що йде на зрошення й нейтралізацію кислотності, розчин на виході 3 насадки буде нейтральним (рис. 4). У разі спалювання мазуту у зв'язку з неможливістю використання конденсаційних поверхонь концентрації токсичних викидів на виході із сухої конвективної поверхні котлів залишаться на рівні їх концентрації на виході з топки допоміжного котла або камери згоряння ДВЗ.

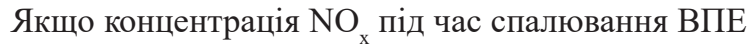
знижується порівняно 3 режимом спалювання безводного мазуту в 3,2 раза, то навіть без урахування впливу процесів абсорбції конденсаційних поверхонь і врахування збільшення абсорбційних властивостей димових газів за еквімолярного відношення $\mathrm{NO}_{2}$ : $\mathrm{NO}$ розміри секції для уловлення $\mathrm{NO}_{x}$ зменшаться в 3-4 рази, а секції уловлення $\mathrm{SO}_{2}$ у урахуванням зростання абсорбції $\mathrm{SO}_{2}$ за нітрозного механізму - у 5-8 разів, оскільки буде створено умови, що $є$ аналогічними під час сірчанокислотного виробництва 3 нітрозним механізмом (концентрація $\mathrm{H}_{2} \mathrm{SO}_{4}$ на рівні $57 \%$, відношення $\mathrm{NO}_{2}$ : $\mathrm{NO}$ на рівні 0,33 ).

З урахуванням ефективності скрубера, що застосований, на відміну від прототипу й аналогів, забезпечується суттєве зниження концентрації $\mathrm{NO}_{\text {x }}$ до $99 \mathrm{M \Gamma} / \mathrm{M}^{3}$, $\mathrm{SO}_{2}$ - до 165 мг/м ${ }^{3}$ за газовим трактом до місця встановлення скруберів (рис. 4). У результаті абсорбції у скрубері $\mathrm{NO}_{\text {x }}$ можна зменшити до $20 \mathrm{мг} / \mathrm{M}^{3}, \mathrm{SO}_{2}-$ до $\sim 33 \mathrm{Mг} / \mathrm{M}^{3}$, а $\mathrm{CO}_{2}$ - до 5,1\% об. Таким чином, використання скруберних технологій під час спалювання ВПЕ $3 \mathrm{~W}^{\mathrm{r}}=25-30 \%$ дає змогу знизити концентрацію $\mathrm{NO}_{\mathrm{x}} \mathrm{y}$ 26 разів, $\mathrm{SO}_{2}$ - у 13,6 раза, а $\mathrm{CO}_{2}$ - у 2,4 раза порівняно зі спалюванням мазуту.

Рис. 4. Зниження викидів шкідливих речовин у разі використання ВПЕ із застосуванням скруберної технології для допоміжних котлів

\section{ВИСНОВКИ}

Експериментальні дослідження показали, що внаслідок дії кавітаційної підготовки води та ВПЕ відбувається зниження на виході з камери згоряння $\mathrm{NO}_{\text {х }}$ 3,8 раза (з $533 \mathrm{мг} / \mathrm{M}^{3}$ до $167 \mathrm{мг} / \mathrm{m}^{3}$ ), $\mathrm{SO}_{2}$ - у 2,5 раза (iз $449 \mathrm{мг} / \mathrm{M}^{3}$ до $\left.183 \mathrm{мг} / \mathrm{M}^{3}\right), \mathrm{CO}_{2}$ - в 1,4 раза (з 12,2 до 8,5). 
Якщо концентрація $\mathrm{NO}_{\text {х }}$ під час спалювання ВПЕ знижується порівняно 3 режимом спалювання безводного мазуту в 3,2 раза, то навіть без урахування впливу процесів абсорбції конденсаційних поверхонь і врахування збільшених абсорбційних властивостей димових газів за еквімолярного відношення $\mathrm{NO}_{2}: \mathrm{NO}$ розміри секції скрубера для уловлення $\mathrm{NO}_{\text {x }}$ зменшать- ся в 3-4 рази, а секції уловлення $\mathrm{SO}_{2}$ з урахуванням зростання абсорбції $\mathrm{SO}_{2}$ за нітрозного механізму - у 5-8 разів. Секція абсорбції $\mathrm{CO}_{2}$ зменшиться в 1,4 раза.

Завдяки зниженню мінімального значення температури стінки на виході газів із допоміжних та утилізаційних котлів теплові викиди під час спалювання ВПЕ з водовмісткісю 30\% знижуються в 1,6 раза.

\section{REFERENCES}

[1] Skeltved, O. (2010). CIMAC NMA Norway (27 January 2010): System solutions for reduction of exhaust gas emissions. Retrieved from: https:/www.sintef.no/globalassets/upload/marintek/cimac2010/man-ole-skeltved.pdf [in English].

[2] Pure $\mathrm{SO}_{x}$. Exhaust gas cleaning (EMD00281EN 1208). Retrieved from: http://www.alfalaval.com/industries/marine/ oiltreatment/Documents/PureSOx\%20product\%20brochure.pdf [in English].

[3] Ecospec CSNOxTM Broshure. Retrieved from: http://www.ecospec.com/upload/brochurepdf/67_uaez4cere8bt2axq15896m gz76wsbasv.pdf [in English].

[4] Landet, R.D. (2010). PM emissions and $\mathrm{NO}_{\mathrm{x}}$-reduction due to water in fuel emulsions in marine diesel engines : Student thesis ; Norwegian University of Science and Technology, Department of Marine Technology. Retrieved from: https:// ntnuopen.ntnu.no/ntnu-xmlui/bitstream/handle/11250/237793/375078_FULLTEXT01.pdf?sequence=1 [in English].

[5] Gorbov, V.M. (2010). Entsiklopediya sudovoy energetiki: uchebnik [Encyclopedia of ship energy: a textbook]. Nikolaev: NUK [in Russian].

[6] Pakhomov, Yu.A., Korobkov, Yu.P., Dmitrievskiy, E.V., Vasil'ev, G.A. (2004). Toplivo i toplivnye sistemy sudovykh dizeley [Fuel and fuel systems of marine diesel engines]. Moscow: RKonsul't [in Russian].

[7] Parsadanov, I.V., Teplitskiy, A.A., Solodovnikov, V.V., Velik, S.Yu. (2011). Primenenie vodotoplivnoy emul'sii v avtotraktornom dizele. Ekologicheskaya effektivnost' (chast' 1) [The use of water-fuel emulsion in automotive diesel engine. Environmental efficiency (part 1)]. Dvigateli vnutrennego sgoraniya, no. 2, pp. 118-120 [in Russian].

[8] Amelin, A.G. (1967). Proizvodstvo sernoy kisloty [Sulfuric acid production]. Moscow: Khimiya [in Russian].

[9] Ramm, V.M. (1975). Absorbtsiya gazov [Gas absorption]. Moscow: Khimiya [in Russian].

[10] Horiachkin, V.Yu., Horiachkin, A.V., Akimov, O.V., Korniienko, V.S., Filipshchuk, O.M., Tenditnyi, Yu.H. (2017). Sposib pidhotovky vodopalyvnoi emulsii dlia enerhetychnykh ustanovok, v yakykh spaliuietsia sirchyste orhanichne palyvo: patent Ukrainy 115037 [Method of preparing water-fuel emulsion for power plants burning sulfuric organic fuel: patent of Ukraine 115037], Applicant Admiral Makarov National University of Shipbuilding, published September 11, 2017; Newsletter № 17 [in Ukrainian].

[11] Viten'ko, T.N., Gumnitskiy, Ya.M. (2007). Mekhanizm aktiviruyushchego deystviya gidrodinamicheskoy kavitatsii na vodu [The mechanism of the activating effect of hydrodynamic cavitation on water]. Khimiya i tekhnologiya vody, vol. 29, no. 5, pp. 422-432 [in Russian].

[12] Horiachkin, V.Yu., Horiachkin, A.V., Akimov, O.V., Iutinskyi, V.O., Korniienko, V.S. (2012). Sposib zakhystu metalu nyzkotemperaturnykh poverkhon nahrivu kotla vid sirchanokyslotnoi korozii: patent na vynakhid 99408 Ukraina [Method of protecting metal of low temperature surfaces of boiler heating from sulfuric acid corrosion: patent for invention 99408 Ukraine], МПК С23F 11/10, F22B 37/00, F23J 15/00; Applicant Admiral Makarov National University of Shipbuilding, published August 10, 2012; Newsletter № 15 [in Ukrainian].

\section{СПИСОК ВИКОРИСТАНОЇ ЛІТЕРАТУРИ}

[1] Skeltved O. CIMAC NMA Norway (27 January 2010): System solutions for reduction of exhaust gas emissions. URL: https://www.sintef.no/globalassets/upload/marintek/cimac2010/man-ole-skeltved.pdf (дата звернення: 04.09.2013).

[2] Pure $\mathrm{SO}_{\mathrm{x}}$. Exhaust gas cleaning (EMD00281EN 1208). URL: http://www.alfalaval.com/industries/marine/oiltreatment/ Documents/PureSOx\%20product\%20brochure.pdf (дата звернення: 04.03.2013).

[3] Ecospec CSNOxTM Broshure. URL: http://www.ecospec.com/upload/brochurepdf/67_uaez4cere8bt2axq15896mgz76wsba sv.pdf (дата звернення: 04.09.2013).

[4] Landet R.D. PM emissions and $\mathrm{NO}_{\mathrm{x}}$-reduction due to water in fuel emulsions in marine diesel engines : Student thesis ; Norwegian University of Science and Technology, Department of Marine Technology (21 June 2010). URL: https:// ntnuopen.ntnu.no/ntnu-xmlui/bitstream/handle/11250/237793/375078_FULLTEXT01.pdf?sequence=1 (дата звернення: 04.09.2013),

[5] Горбов В.М. Энциклопедия судовой энергетики : учебник. Николаев : НУК, 2010. 624 с.

[6] Топливо и топливные системы судовых дизелей / Ю.А. Пахомов, Ю.П. Коробков, Е.В. Дмитриевский, Г.А. Васильев. Москва : РКонсульт, 2004. 464 с.

[7] Применение водотопливной эмульсии в автотракторном дизеле. Экологическая эффективность (часть 1) / И.В. Парсаданов, А.А. Теплицкий, В.В. Солодовников, С.Ю. Велик. Двигатели внутреннего сгорания. 2011. № 2. С. 118-120.

[8] Амелин А.Г. Производство серной кислоты. Москва : Химия, 1967. 472 с.

[9] Рамм В.М. Абсорбция газов. Москва : Химия, 1975. 655 с. 


\section{ЕНЕРГЕТИЧНЕ МАШИНОБУДУВАННЯ № 3 - 2019}

[10] Спосіб підготовки водопаливної емульсії для енергетичних установок, в яких спалюється сірчисте органічне паливо : патент України 115037 / В.Ю. Горячкін, А.В. Горячкін, О.В. Акімов, В.С. Корнієнко, О.М. Філіпщук, Ю.Г. Тендітний ; заявник Національний університет кораблебудування імені адмірала Макарова ; заявл. 06.03.2014 ; опубл. 11.09.2017, бюл. № 17.

[11] Витенько Т.Н., Гумницкий Я.М. Механизм активирующего действия гидродинамической кавитации на воду. Химия и технология водыл. 2007. Т. 29. № 5. С. 422-432.

[12] Спосіб захисту металу низькотемпературних поверхонь нагріву котла від сірчанокислотної корозії : патент на винахід 99408 Україна, МПК С23F 11/10, F22B 37/00, F23J 15/00 / В.Ю. Горячкін, А.В. Горячкін, О.В. Акімов, В.О. Іутінський, В.С. Корнієнко ; заявник Національний університет кораблебудування імені адмірала Макарова ; заявл. 23.08.2011; опубл. 10.08.2012, бюл. № 15. 